\title{
Reino de Deus e Opção pela Insignificância A partilha da mesa, símbolo e sinal da relação de Jesus com os pobres, como paradigma para a sacramentalidade eclesial
}

\author{
Orientador: Ana Maria A. L. Tepedino
}

Mestrando: Sérgio Albuquerque Damião

Área de Concentração: Teologia Sistemático-Pastoral

Linha de Pesquisa: Religião e Modernidade

O Concílio Vaticano II buscou aproximar novamente a Igreja da sociedade através do diálogo e do serviço. Este impulso dado pelo Concílio repercute na Igreja latino-americana desencadeando uma tomada de consciência de seu papel junto à realidade que lhe circundava. Para isto a utilização das análises provenientes das ciências sociais ajudará na percepção da realidade. Isto desembocará em uma Igreja que procurará estar mais atuante junto à população marginalizada da sociedade, defendendo seus direitos e sua vida. Entretanto, atualmente, apesar dos pronunciamentos oficiais, existe um incômodo silêncio eclesial no que tange a pobreza e seus rostos. Dentro deste movimento, este trabalho visa discorrer sobre a sacramentalidade da Igreja, sua vinculação ao Reino de Deus e consequente inserção no contexto atual, que apresenta novos desafios para a comunidade eclesial e sua configuração. Neste intuito, apresentamos uma breve análise acerca do significado conceitual do termo pobreza e suas implicações. E, a partir da "comensalidade aberta" estabelecida por Jesus e suas conseqüências, delineamos perspectivas eclesiológicas que apontem caminhos para a construção contínua de uma Igreja que seja cada vez mais Sacramento do Reino.

Palavras-chave: Reino de Deus; Sacramento; Igreja; Pobreza; Mesa; Comensalidade Aberta. 